ENTREPRENEURSHIP AND SUSTAINABILITY ISSUES

ISSN 2345-0282 (online) http://jssidoi.org/jesi/

2020 Volume 7 Number 3 (March)

http://doi.org/10.9770/jesi.2020.7.3(50)
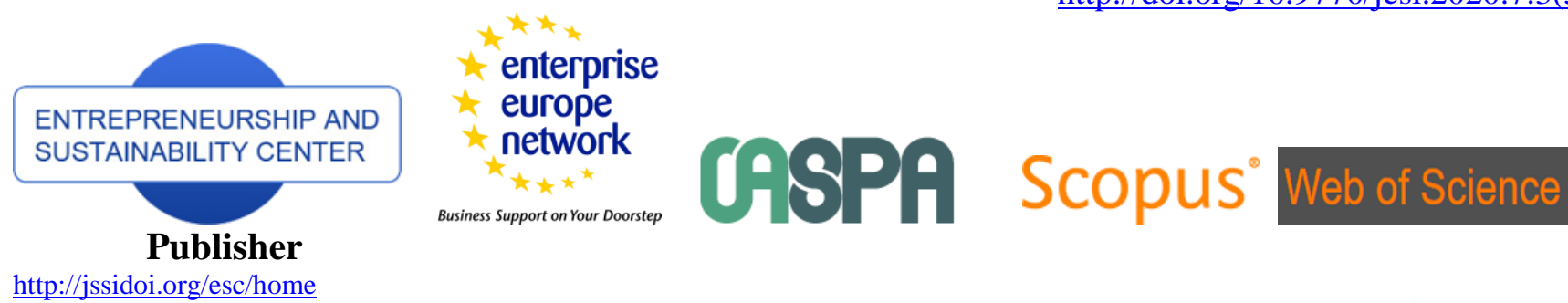

http://jssidoi.org/esc/home

\title{
HEALTH TOURISM IN LOW MOUNTAINS: A CASE STUDY
}

\author{
Alexandr N. Dunets ${ }^{1 *}$, Veronika V. Yankovskaya ${ }^{2}$, Alla B. Plisova ${ }^{3}$, Mariya V. Mikhailova ${ }^{4}$, \\ Igor B. Vakhrushev ${ }^{5}$, Roman A. Aleshko ${ }^{6}$ \\ ${ }^{1}$ Altai State University, Lenin Ave., 61, 656049, Barnaul, Russian Federation \\ ${ }^{2}$ Plekhanov Russian University of Economics, Stremyanny lane, 36, 117997, Moscow, Russian Federation \\ ${ }^{3}$ Financial University under the Government of the Russian Federation, Leningradsky Prospekt, 49, 125993, Moscow, \\ Russian Federation \\ ${ }^{4}$ Sechenov First Moscow State Medical University, Trubetskaya st., 8-2, 119991, Moscow, Russian Federation \\ ${ }^{5}$ V.I. Vernadsky Crimean Federal University, Prospekt Vernadskogo 4, Simferopol, 295007, Russian Federation \\ ${ }^{6}$ Northern (Arctic) Federal University, Severnaya Dvina Emb. 17, 163002, Arkhangelsk, Russian Federation

$$
\text { E-mails: }{ }^{1 *} \text { dunets@mail.ru; }
$$

Received 14 August 2019; accepted 20 December 2019; published 30 March 2020

\begin{abstract}
Health tourism is a specific type of tourism with great prospects. Most people do not have time for long trips, but there is a great need for a change of scenery and restoration of strength. There are many examples when in the regions in order to improve health and relaxation, nearby areas are being developed. It is most promising to create programs for such tourism near existing resorts that have the necessary infrastructure and medical facilities, while individual client requests must be taken into account. It is proposed to research health tourism as a territorial tourist complex, which includes not only specialized infrastructure but also territories adjacent to resorts. It is noted that low-mountain areas have the most suitable spaces for tourism development. By the example of the Belokurikha resort, the goals of visiting and tourist satisfaction are identified, as well as the possibilities of developing health tourism. A model for designing individual programs for health tourism is proposed.
\end{abstract}

Keywords: health tourism; medical tourism; low-mountain areas

Reference to this paper should be made as follows: Dunets, A.N., Yankovskaya, V.V., Plisova, A.B., Mikhailova, M.V., Vakhrushev' I.B, Aleshko, R.A. (2020). Health tourism in low mountains: a case study. Entrepreneurship and Sustainability Issues, 7(3), $2213-2227$. http://doi.org/10.9770/jesi.2020.7.3(50)

JEL Classifications: Z32, L83, Q01

Additional disciplines ecology and environment; geography

\section{Introduction}

Health tourism has a long history. Its formation is based on the use of medical resources and the use of medical procedures. Health tourism consists of disease prevention, including specific disease prevention and Wellness tourism, and medical tourism, which includes surgery and treatment of diseases. Many medical resorts were 


\section{ENTREPRENEURSHIP AND SUSTAINABILITY ISSUES}

ISSN 2345-0282 (online) http://jssidoi.org/jesi/

2020 Volume 7 Number 3 (March)

http://doi.org/10.9770/jesi.2020.7.3(50)

created in low mountains. This is due to the presence of mineral waters, clean air, the landscape attractiveness of the mountains and a favorable climate.

Currently, it is required to take a fresh look at the old forms of organization of treatment and rest on the basis of sanatoriums. New trends are increasing the requirements of consumers of services to the quality of service, reducing free time on vacation, the search for such programs that can diversify and personify relaxation and treatment. It is important to take into account the needs of tourists and promote the development of health tourism, which will make it possible to diversify segments of tourists and increase tourist flows in traditional health resorts. It is relevant to identify what opportunities existing sanatoriums and resorts have in connection with the development of health tourism in the adjacent territory. For this, it is necessary to identify the features of the organization of this type of tourism and the needs of tourists (Goryushkina et al., 2018, 2019; Ozen and Grima, 2018; Almeida et al., 2019; Singgalen et al., 2019; Chehabeddine, Tvaronavičienè, 2020; Caurkubule et al. 2020).

Many old resorts have the image of places where they treat pensioners and people after serious illnesses. Sanatoria have the opportunity to provide a new list of services and more successfully develop health tourism. Since most modern people are stressed, they have poor health and need to change their environment.

Due to the fact that the development of health tourism is based on the creation of centers with specialized infrastructure (sanatoriums, medical centers), it becomes necessary to analyze existing examples of territorial tourist complexes. The Belokurikha resort, the largest resort in the Asian part of Russia located in the low mountain zone, can be used to study and simulate the current state of the services offered and the possibility of the emergence of new programs for health tourism.

\section{Literature review}

Health tourism is a market of almost half a trillion dollars, accounting for $14 \%$ of the total global tourism revenue. Health tourism has traditionally been an important and popular type of tourism in Russia. Various and numerous natural healing factors, a well-developed network of sanatorium and resort organizations, training of medical personnel, and the scientific substantiation of balneologists are the basis for further development (Tourism in Russia: A Management Handbook..., 2015).

The development of health tourism and medical tourism in modern practice is often associated with the SPA industry. These are wellness programs consisting of special hydrotherapy procedures using mineral or fresh water combined with the healing effects of therapeutic mud, algae, plant products and other components of natural origin.

The Annual Medical Tourism Report presents the range of treatment options available to potential tourists and includes: cosmetic surgery; dentistry; cardiology/cardiac surgery; orthopedic surgery; stomach treatment; reproductive system; organ, cell and tissue transplantation; eye surgery; diagnostics and screening (Lunt et al. 2019).

According to the UNWTO definition (UNSD and UNWTO, 2008), health tourism includes services that vary widely from visits to spa centers to surgical operations (Vetitnev et al., 2012). Hajioff (2007) defines this concept as a trip to other countries or territories for the purpose of acquiring medical and related health services, which is close to the concept of medical tourism.

Vetitnev (2012) defines health tourism as part of a tourist activity that involves, as the main motive for travel, obtaining by tourists a complex of curative, diagnostic, rehabilitation, preventive and recreational services 


\section{ENTREPRENEURSHIP AND SUSTAINABILITY ISSUES}

ISSN 2345-0282 (online) http://jssidoi.org/jesi/

2020 Volume 7 Number 3 (March)

http://doi.org/10.9770/jesi.2020.7.3(50)

provided in areas other than their place of permanent residence and having the necessary natural, material and human resources to prevent diseases or treatment. Wellness tourism is distinguished by the fact that consumers of services have the main motive - preserving and strengthening their health, preventing the disease, and not its treatment (Muller, and Lanz Kauffman, 2001).

Health tourism suggests that tourists receive the medical and recreational services provided in areas with natural resources as the main motive for the trip. Various aspects of the development of health tourism are reflected in the publications (Health \& Wellness Tourism... 2009; Vetitnev, 2012; Lautier, 2014; Sandberg, 2017 et al.). Health tourism consists of two main parts. The first is disease prevention, which includes specific types of disease prevention and wellness tourism. The second component is medical tourism, which includes surgery and treatment of diseases (Typology of Tourism..., 2008).

Health tourism is a combined type of tourism and includes two components: medical and recreational. In this regard, health tourism has an expanded segment of tourists; these are both people with diseases and various categories of tourists who can be classified as conditionally healthy. In addition to the use of infrastructure and medical resources, health tourism has an extra function - recreational, associated with the active movement of tourists in the areas adjacent to the resort (Watkins et al., 2018; Yemelyanov et al., 2018; Trofimova et al., 2019; Prodanova et al., 2019). For example, in the territories adjacent to the resort, terrains are arranged using mountainous terrain. At the intersection of hiking trails, parking with food and rest points is created, places for heliotherapy are determined taking into account the microclimatic features of the area. The implementation of tourist programs in the natural environment allows vacationers to observe birds, animals, plants, get acquainted with the geological features of the territory. In organizing such tourism, traditional wellness treatments (saunas, massages, herbal teas, salt) and therapeutic exercises (for example, oriental areas such as wushu, yoga) can be widely used.

The target segments of health tourism can be various groups of tourists, not only having diseases but also healthy people who want to get a healing effect from tourist resources and implemented medical technologies. This type of tourism makes it possible to realize the functions of recreation associated with the restoration of physical and emotional strength (Pavlov, 2017; Voronkova et al., 2019; Zeibote et al., 2019; Mullakhmetov et al., 2018; Bernardi, 2019).

At present, the work of the organizers of health tourism on the development of anti-stress programs enjoys particular success and prospects for further development (Sharafutdinov et al., 2017, 2019; Nelyubina et al., 2016; Kolupaev et al., 2019; Feofanovich, 2019). It is stress that largely contributes to the development of a number of diseases; therefore, the creation of such programs for healthy people is especially important. As a rule, they are short (two to three days) and include hiking trails and wellness treatments.

The use of surrounding natural resources is one of the necessary conditions for the development of health tourism, in connection with which they are subject to special requirements, including the preservation of the environment, the absence of a pronounced anthropogenic load. It is the presence in natural conditions and the positive impact of climate, forest resources, and landscape features that largely contribute to stress relief, positive mood and general recovery of the tourist. Low-mountain areas are particularly suitable for this. The attractiveness of foothill and low-mountain regions is determined by a favorable climate and most often by good transport accessibility.

Natural factors act as a basic basis for the development of tourist activities in any territory (Ghosh and Ghosal, 2019; Korableva et al., 2018). In some forms of tourism, they are of paramount importance - therapeutic and health-improving recreation (mineral waters, mud, landscape and climatic conditions); in others, they are relegated to the background and form only the environment for development (for example, excursions) (Oborin, 2011). The complex of natural healing resources of health tourism includes geological and geomorphological, 


\section{ENTREPRENEURSHIP AND SUSTAINABILITY ISSUES}

ISSN 2345-0282 (online) http://jssidoi.org/jesi/

2020 Volume 7 Number 3 (March)

http://doi.org/10.9770/jesi.2020.7.3(50)

climatic, aquatic, biological, faunistic and floristic resources (Mirzekhanova and Koltsova, 2013; Ziyadin et al., 2018; Madiyarova et al., 2019; Rahman et al., 2017).

The nature of the surface of the territory is of paramount importance in the differentiation of the territory for health tourism. Its elevation above sea level and the strong ruggedness of the relief determine the exceptional variety of properties and objects of the natural environment.

With an increase in absolute height, the characteristics of the living environment of organisms quickly change within small distances and have a great impact on life support processes. In the mountains, there is a high-altitude interval of ecological optimum for the life and activity of people (Suprunenko, 2003).

The main characteristics of the relief are the absolute and relative height. For the development of health tourism, it is advisable to use territories with absolute heights of up to 2 thousand meters, as excessive effects on the human body arise above. However, there are examples of resorts located at an altitude of 3 thousand meters (for example, in the Pamirs). In this case, the treatment uses the special natural conditions of the area (clean air and its ionization, atmospheric pressure, oxygen and ozone, etc.).

The main most comfortable relief parameters for health tourism purposes include the following: absolute height $1000 \mathrm{~m}$; slope steepness $-0-10^{\circ}$; surface substrate - pebble, sand, loam; depth of snow cover $-0-20 \mathrm{~cm}$; condition of the snow surface - dry, crumbly snow; gentle forms of the surface with the presence of landscape places, rocks. Bredikhin (2004) identified criteria for assessing the influence of relief on the formation and functioning of various types of territorial tourism systems. Among others, he identified a therapeutic-recreational type that has three subtypes: climatic, mud and balneological. In the mountains, humidity is reduced, air ionization and solar radiation are increased, which has a beneficial effect on various body systems. Of particular importance for health tourism are the properties of the substrate, the hydrogeological and geochemical characteristics of the territory (the chemical composition of mineral waters and muds, their reserves, flow rates, the nature of occurrence and outcrops to the surface, etc.).

\section{Methods}

Due to the fact that health tourism is a combined type of tourism, a system-integrated approach to research can be used to identify its development. Preobrazhensky (1975) proposed the use of a systematic approach to the study of tourism in Russia. From the economic point of view, the territorial tourist system in the region is the territorial health tourism complex. Krotova (2003) notes that when the tourist complex is formed, intersectoral relations develop.

The existence of health tourism involves the development of the relationship between medicine and the tourism sector. Medical centers with specialized infrastructure should take into account the needs of tourists and use tourism resources.

The sociological method is important to identify the needs of tourists, which are the basis for the functioning of the territorial tourist complex. Questionnaires and surveys help to identify tourist satisfaction with the services provided and needs for new services (Kim, Bahlaitner, 2006).

Territorial health tourism complexes are urban education formations of the medical and recreational functional profile, consisting of institutions united by a single architectural and planning solution, a common spatial composition and organization of services. Tourism complexes are not only buildings, structures, other artificial and technical objects but also the territory itself with all the features of its natural landscape. Therefore, in Russia, there are such concepts as a resort protection zone or a health-improving area (Federal Law No. 26-FZ "On Natural Healing Resources..., 1995). These territories belong to special categories of lands that are used to organize the treatment and recreation of citizens. The value of such territories lies in the location of certain natural resources on 
them in the form of mineral waters, mud, and in some cases even the climate (mountainous, forest) has a healing effect.

In the territorial and functional aspects, the tourist complex is understood as the corresponding infrastructure or network of tourist and recreational organizations located in territories of different levels. The level of infrastructure development of the tourist complex is characterized by: network development indicators (number of organizations and their capacity); the amount of costs for the development of the network (the number of labor resources); the achieved level of social security (Lukyanova, Tsybuh, 2004).

In the tourist complex, one can distinguish medical institutions that provide medical services to tourists and are the basic elements of health tourism. The special attention is required to the laying of roads and a network of tourist routes near a medical center (resort) in mountainous terrain. This will make it possible to successfully use the territory for health tourism (Fig. 1).

The health tourism complex can be represented in the form of blocks:

- natural resources (primarily climatic, orographic, hydro-mineral, landscape);

- specialized, including medical facilities (motels, clinics, medical centers, etc.);

- tourist and recreation, which includes tourist and hotel enterprises, as well as providing wellness services, organizing excursions and simple trips;

- the management unit provides planning, regulation, coordination and control of the development of enterprises of the tourist complex;

- the production unit provides materials, equipment, food, includes utility networks, engineering infrastructure, and transport;

- social service includes organizations and institutions that provide health tourism consumers with social services (trade, catering, social services, culture and art, science and education, entertainment, information support, communication) (Dunets, 2019).

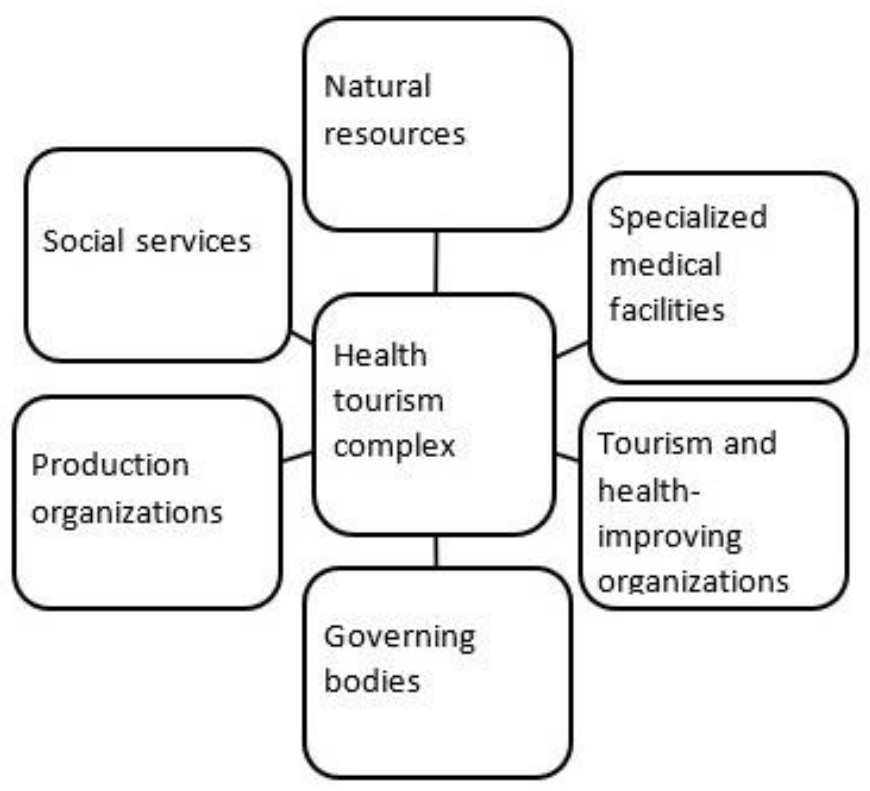

Fig. 1. The structure of the territorial health tourism complex Source: own research 


\section{ENTREPRENEURSHIP AND SUSTAINABILITY ISSUES}

ISSN 2345-0282 (online) http://jssidoi.org/jesi/

2020 Volume 7 Number 3 (March)

http://doi.org/10.9770/jesi.2020.7.3(50)

\section{Results}

The authors have examined the experience of developing the health tourism complex in the low-mountain part by the example of the Belokurikha resort, which is the largest resort in the Asian part of Russia, located in the Altai Mountains. Observations of local residents over the positive influence of warm mineral water contributed to the fact that in 1866, the first bath was set up and treatment was organized, and then a special treatment room was created. In 1916, the first sanatorium was built. In 1960, many new sanatoriums were built: Centersoyuz, Altai, Katun, Russia, Siberia, children's sanatoriums of the Ministry of Health, a radiation therapy center with 80 baths, ZapSib Rodnik, Gornyak sanatorium. In the late 1980s, more than 50 thousand people annually underwent treatment and rehabilitation courses in the sanatoriums of the Belokurikha resort, the resort had a status of national importance. Currently, the resort area of Belokurikha is an independent part of the city of Belokurikha, which stretches along the valley of the river of the same name. The resort has 22 major sanatoriums with a total capacity of about 4.5 thousand beds. More than 240 thousand tourists rest at the resort annually ( 246 thousand in 2019). About 4300 people work at sanatoriums. Such data are provided by the Altai Territory Administration for the Development of Tourism and Resort Activities. The resort has developed mainly the service sector; there are various specialized institutions, as well as ski slopes. Currently, Belokurikha is gaining fame not only as a resort city but also as a venue for major events. The population in the resort city in 2019 is 36.6 thousand people, including 17.9 thousand people of working age (Demographic Yearbook of the Altai Territory, 2019). A feature of the territory of Belokurikha is its location at the junction of the plains of Western Siberia and the Altai Mountains. The area has a dissected low mountainous terrain. Absolute elevations range from $450 \mathrm{~m}$ to $845 \mathrm{~m}$. Relative heights are $100 \mathrm{~m}$ or more. Belokurikha has favorable conditions for the formation of a layer of warm air in the cold season, as a result of which this territory is characterized by less severe winters and a longer frost-free period, in comparison with the plain part of the region. The average air temperature in January in Belokurikha is $-16.8^{\circ} \mathrm{C}$, while in Biysk, $75 \mathrm{~km}$ to the north, it is $-18.2^{\circ} \mathrm{C}$, and in the neighboring mountainous part of Altai, it is $-17.5^{\circ} \mathrm{C}$. The average air temperature in July in Belokurikha is $+19.2^{\circ} \mathrm{C}$.

The moistening mode of the territory is due to the presence of the "barrier effect" mechanism, due to which, when the air masses rise along the slopes, a greater amount of precipitation occurs compared to the plain spaces. In Belokurikha, the precipitation is up to $700 \mathrm{~mm}$. The amount of solar radiation received is quite significant - more than $100 \mathrm{kcal} / \mathrm{cm}^{2}$ (more than $4200 \mathrm{MJ} / \mathrm{m}^{2}$ ) per year. The duration of sunshine is an average of 1925 hours per year, and often it reaches 2100 hours per year. In Belokurikha, the longest warm period is observed - 201 days with a minimum duration of cold compared to neighboring regions (Kharlamova, 2013). The water body used for recreational purposes is the Belokurikha River. The larger Peschanaya River is $10 \mathrm{~km}$ from the resort. The resort uses sulphide-silt therapeutic mud from the lakes of the Altai Territory. Siliceous thermal radon-containing waters predominate (Belokurikha deposit with thermal nitrogen-siliceous radon-containing waters, with a temperature from $30{ }^{\circ} \mathrm{C}$ to $42{ }^{\circ} \mathrm{C}$ ) (Revyakin, Pomorov, Vdovin, 1997). Mineral drinking water is used both from local sources (Belokurikhinskaya Vostochnaya No. 2) and imported from the foothills of Altai - therapeutic-table water Zavyalovskaya. The largest organization in Belokurikha is JSC "Resort Belokurikha" including the sanatoriums Belokurikha, Siberia, Katun, a resort clinic and also other facilities. Large sanatoriums "Altai West", "Russia" and "Transsib" are successfully developing. The resort is characterized by a lack of additional infrastructure aimed at young people, an insufficient number of clubs, shopping and entertainment centers. Additional infrastructure is presented by restaurants and cafes that fully satisfy the needs of tourists. 3-4-star hotels are also mainly located in the resort area. The low-level hotels, guest houses, hostels are located on the periphery. There are a large number of playgrounds in the sanatoriums. The application of sociological analysis of various types of tourism activities associated with health allows identifying tourist preferences and the degree of satisfaction from recreation, treatment, recreation and entertainment programs, etc. The most accessible sociological method is a survey of tourists vacationing in sanatoriums. The profiles of 1700 tourists vacationing in Belokurikha (Sanatoria Belokurikha, Katun, Siberia) were analyzed. The main purpose of staying at the resort is to receive specialized treatment $(32 \%)$ and rehabilitation and prevention (24\%); to a lesser extent, tourists are interested in outdoor activities (10\%) and 
relaxation (7\%). Most of all sanatorium vacations are chosen by workers (28\%), office workers $(21 \%)$ and pensioners (19\%). In general, 97\% of respondents are satisfied with the prescribed course of procedures, attentiveness and professionalism of medical personnel, as well as the quality of service. As for the related services, only $88 \%$ are satisfied with the entertainment programs, $86 \%$ - with sporting events and $68 \%$ - with the organization of children's leisure. Based on the foregoing, the sanatorium copes with the provision of services in the field of treatment, rehabilitation and prevention, but there is a lack of cultural events, programs for outdoor activities, relaxation, etc. (Figures 2-5).

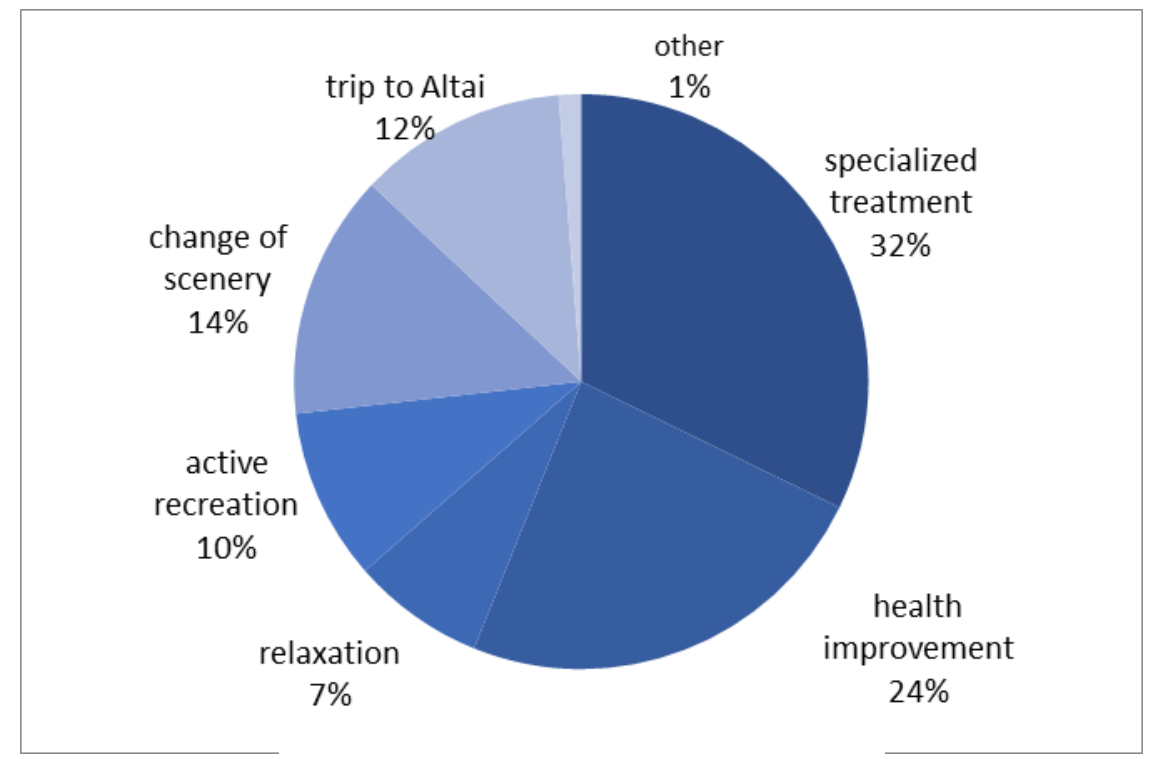

Fig. 2 Purpose of visiting the Belokurikha resort Source: own research

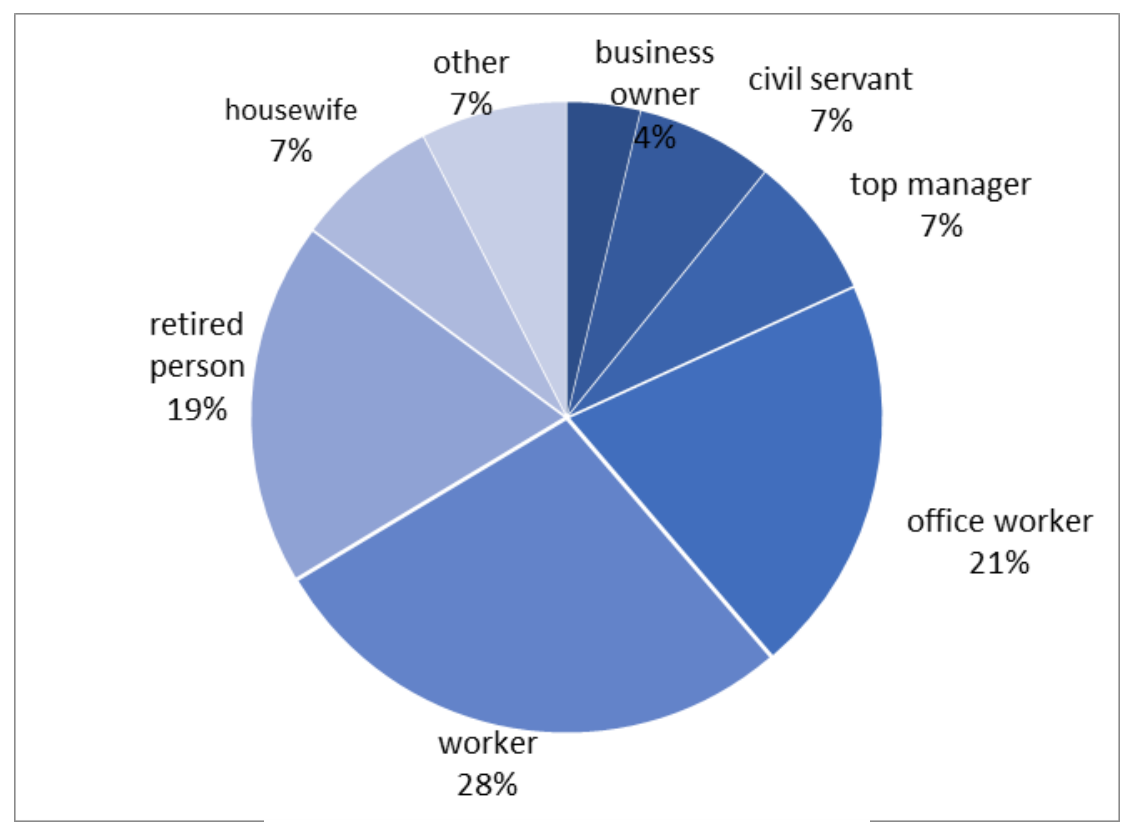

Fig. 3 Professional status of interviewed tourists Source: own research 


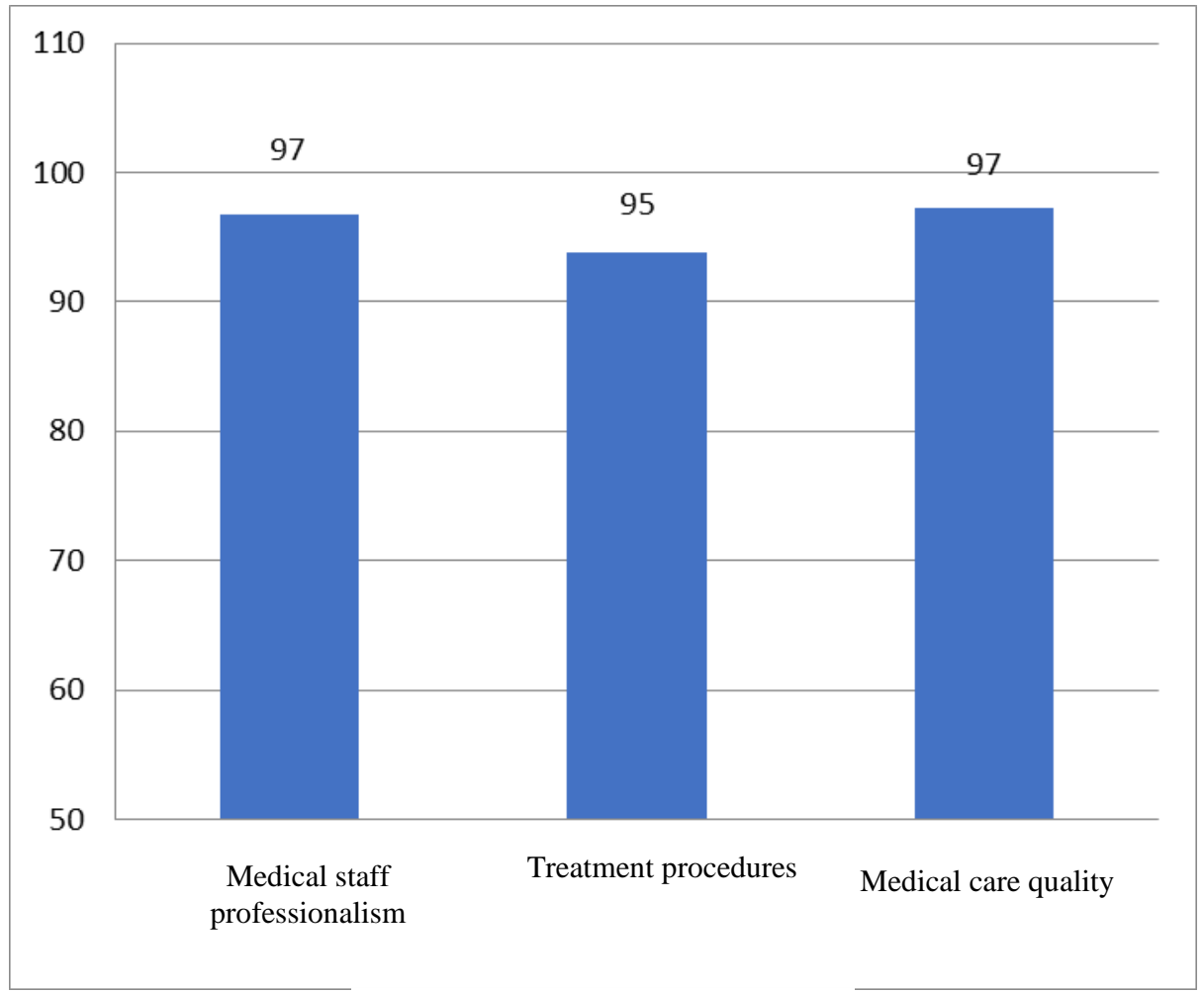

Fig. 4 Satisfaction with medical services Source: own research

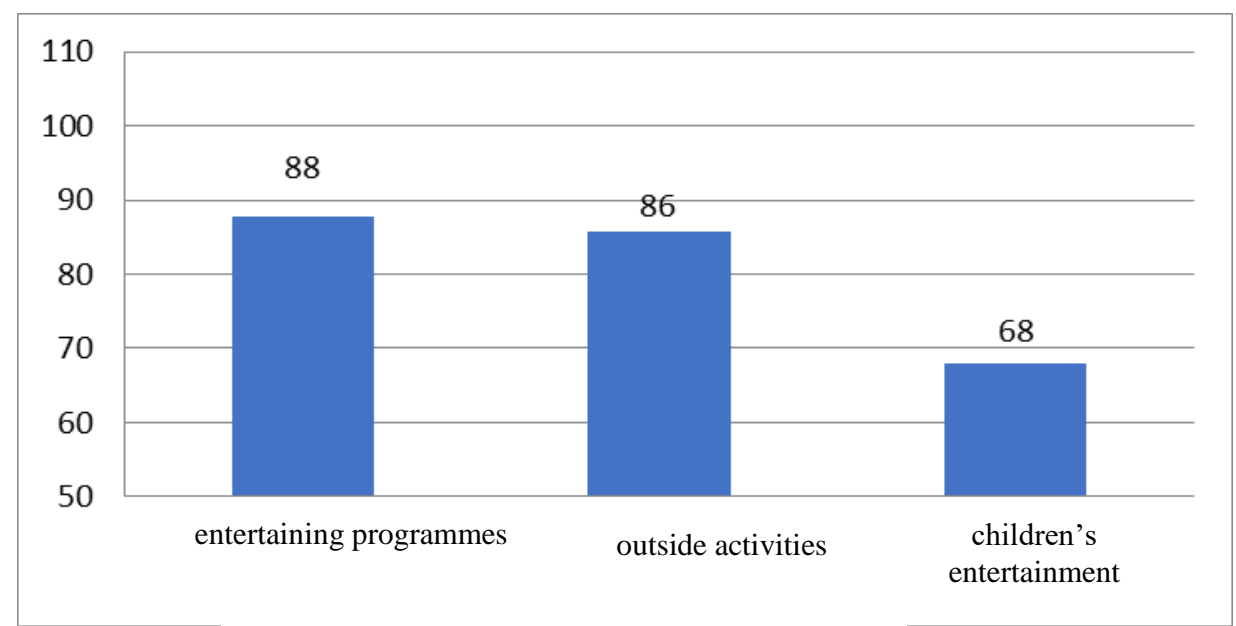

Fig. 5 Satisfaction with additional relaxation programs Source: own research

Currently, several facilities have been created in Belokurikha providing components in health tourism and complementing the medical services of sanatoriums. They are popular with resort guests: a wellness center with a pool and water attractions; "Siberian Compound", including a recreation area, a museum, a hippodrome and stables; "Belokurikha Village"; a complex in the Russian style "Altai Gold" with Sandunov Bath Houses; "Forest Tale" in a secluded place where one can communicate with pets; "Altai Valley" sanatorium at a small distance from the resort. 


\section{ENTREPRENEURSHIP AND SUSTAINABILITY ISSUES}

ISSN 2345-0282 (online) http://jssidoi.org/jesi/

2020 Volume 7 Number 3 (March)

http://doi.org/10.9770/jesi.2020.7.3(50)

Health tourism is of interest to the government and business. The development of health tourism involves the development and implementation of innovative types of partnerships among stakeholders, specific management models. In other words, it is necessary to develop a mechanism for the formation of public-private partnerships in the development of health tourism (Chistobaev et al., 2019; Shevyakova et al., 2019). An example of this was a project in a low-mountain area near the resort of Belokurikha, which was practically not used for tourism. The creation and development of the Belokurikha 2 Gornaya project and financial support from the federal target program "Development of Domestic and Inbound Tourism in the Russian Federation" made it possible to create transport and engineering infrastructure. Hotels and entertainment facilities are being created here, there are horse riding and hiking trails (terrain cure). The concept of the Belokurikha 2 Gornaya project provides for the construction of a resort complex with 3,000 beds, including hotel buildings of low floors, catering facilities, sports and recreational facilities, a fair area with retail pavilions, a spa clinic, a physiotherapy clinic, a balneotherapy center, an aesthetic medicine center, a wellness park, and a beach area with a water park. Belokurikha 2 Gornaya will be able to receive more than 200 thousand tourists a year.

The analysis of the state and development prospects of Belokurikha as a health tourism destination revealed their territorial structure:

the area of the enterprise (sanatorium, medical center, etc.) is a health tourism center;

the walking area within the village is a tourist center (resort);

the area of terrain cure and hiking routes;

the zone of nearby routes to tourist resources (for example, lakes);

the border zone of tourist destinations (borders are blurred and change over time, and also "pulsate" depending on the season of the year).

The development of these zones is determined by new opportunities for the resort, which are associated with the expansion of tourism segments and an increase in tourist flow.

For the development of health tourism, the tour organizer needs to understand how various services or types of medical procedures (therapies) can interact, comprehensively influencing the human body. Personalization of programs consists in the selection of medical and physiological factors for a particular person, which in reality is difficult to implement. Nevertheless, it is advisable to segment the tourists, offering them the appropriate leisure program package.

The creation of health tourism programs can be based on the hierarchical principle of recreational design by Kvartalnov and Zorin (2001). This can be represented as a combination of recreational activities (targeted, additional, attendant), depending on the main characteristics of tourists, due to their level of health (Fig. 6) (Kvartalnov et al., 2001). Targeted recreational activities should include therapeutic methods and influence on the human body. Based on a combination with additional recreational activities, as well as related services, individual health tourism programs are formed. 


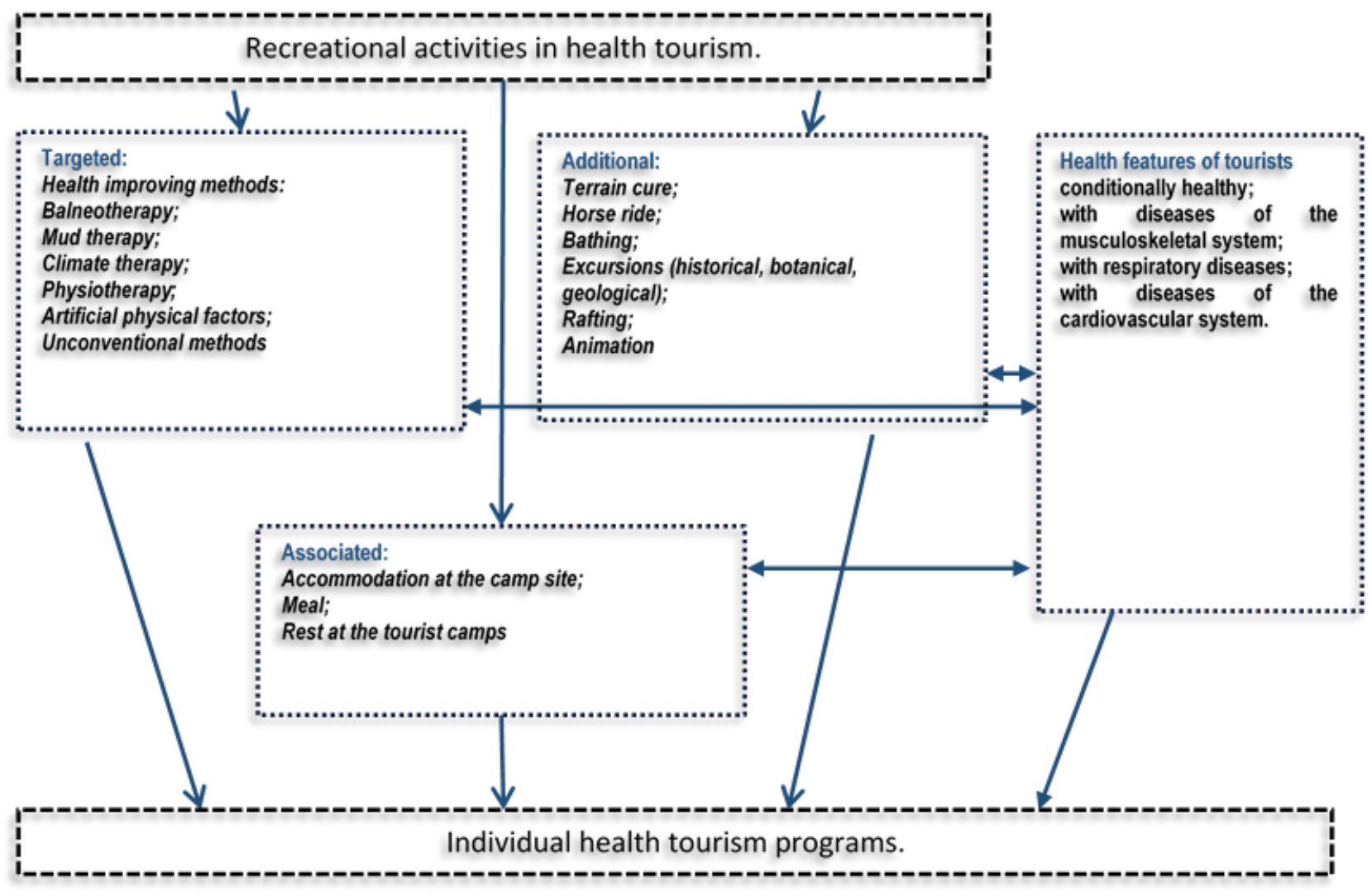

Fig. 6. Types of recreational activities used in the formation of individual health tourism programs Source: own research

\section{Discussion}

Natural and territorial features determine the possibilities for the development of health tourism (relief and landscape, climatic comfort, the availability of minerals used for therapeutic purposes). The special infrastructure that provides medical services, accommodation for tourists, as well as with their movement by vehicles, determines the prospects of health tourism.

When assessing the territory, it is necessary to take into account not only the absolute height of the terrain but also the degree of dissection of the relief, which is characterized by the depth and density of the dissection, as well as the steepness of the slopes. For health tourism purposes, a large-hilly or low-mountain undulating relief is most favorable. The flat surface is aesthetically less expressive and unfavorable for tourist activities. The characteristics of the terrain are especially important when laying the terrain cure routes. They are a prerequisite for the functioning of modern resorts, as they are used to train the cardiovascular system, musculoskeletal system, and respiratory system. 


\section{ENTREPRENEURSHIP AND SUSTAINABILITY ISSUES}

ISSN 2345-0282 (online) http://jssidoi.org/jesi/

2020 Volume 7 Number 3 (March)

http://doi.org/10.9770/jesi.2020.7.3(50)

\section{Conclusions}

Thus, health tourism is characterized by combined elements in the tourism program, and therefore these programs are selected individually (personalization of leisure), taking into account the level of health of tourists. In this case, the medical element is required for the organization of this type of tourism. Therefore, health tourism is concentrated near sanatoriums and medical centers.

Allowance for the needs of tourists and the development of health tourism will make it possible to diversify segments of tourists and increase tourist flows in traditional health resorts. It is relevant to identify what opportunities existing sanatoriums and resorts have in connection with the development of health tourism in the adjacent territory.

Health tourism includes elements of tourist routes that are aimed at restoring the physical, emotional and psychological strength of a person. Tourism programs may include edutainment and sports elements.

The influence of natural environmental factors on the health and livelihoods of people is obvious. For the implementation of health tourism, the presence of certain properties of the territory is required, allowing the most efficient implementation of the healing and treatment processes. These include a set of natural factors: orographic, climatic, water, balneological (mineral springs, healing mud, etc.), etc.

\section{References}

Almeida, M. V. D. A., Silva, E. M. D., Gomes, N. Â., Nunes, L. A. O., \& Curi, W. F. (2019). Environmental quality of campina grande landfill based on technical and operational aspects. [Qualidade ambiental do aterro sanitário de campina grande com base em aspectos técnicos e operacionais] Periodico Tche Quimica, 16(32), 77-86.

Bernardi, A. (2019). The capability approach and organizational climate as tools to study occupational health and safety. Insights into Regional Development, 1(2), 155-169. https://doi.org/10.9770/ird.2019.1.2(6)

Bredikhin A. V. (2004). Relief as a recreational condition and a resource of tourism. Vestnik of Moscow University. Ser. 5. Geography. No. 4. P. 23-28.

Caurkubule, Zh. L., Kenzhin, Zh. B. Bekniyazova, D.S., Bayandina, G.D., Dyussembekova, G. S. (2020). Assessment of competitiveness of regions of the Republic of Kazakhstan. Insights into Regional Development, 2(1), 469-479. http://doi.org/10.9770/IRD.2020.2.1(6)

Chehabeddine, M., Tvaronavičienè, M. (2020). Securing regional development. Insights into Regional Development, 2(1), 430-442. http://doi.org/10.9770/IRD.2020.2.1(3)

Chistobaev A.I., Semenova Z.A., Grudtsyn N.A. (2019). Management of partnership between the state and business in health tourism. Bulletin of the NAT No. 3 (51) July-September. P. 32-35

Demographic Yearbook of Altai Territory: Stat.sb. (2019). Office of the Federal State Statistics Service for the Altai Territory and the Republic of Altai. - B., 160 p.

Dunets A., Penkova A., Potekhina E., Gribkova O., Nikolaeva A., \& Smirnov D. (2019) Cluster as a form of Resort Development: Organizational and Managerial Structure. International Journal of Innovative Technology and Exploring Engineering (IJITEE), 9(1), 36623668

Federal Law of February 23, 1995 N 26-Federal Law "On Natural Healing Resources, Health-Improving Areas and Resorts", publ. In "Rossiyskaya Gazeta" dated March 1, 1995 N 44, in the Collection of Legislation of the Russian Federation dated February 27,1995 N 9 Art. 713 


\section{ENTREPRENEURSHIP AND SUSTAINABILITY ISSUES}

ISSN 2345-0282 (online) http://jssidoi.org/jesi/

2020 Volume 7 Number 3 (March)

http://doi.org/10.9770/jesi.2020.7.3(50)

Feofanovich, B. E. (2019). One approach to compact testing of digital circuits. Journal of Applied Engineering Science, 17(1), 26-34.

Ghosh, M., \& Ghosal, S. (2019). Historical geography of forestry and forest culture in sub-himalayan west Bengal, 1757-2015. Space and Culture, India, 6(5), 215-227. https://doi:10.20896/SACI.V6I5.393

Goryushkina, N. E., Gaifutdinova, T. V., Logvina, E. V., Redkin, A. G., Kudryavtsev, V. V., \& Shol, Y. N. (2019). Basic principles of tourist services market segmentation. International Journal of Economics and Business Administration, 7(2), 139-150.

Goryushkina, N. E., Vakhrushev, I. B., Akhmetova, M. K., Otto, O. V., Pesotskaya, E. V., \& Voinova, N. E. (2018). The world hotel market: Current state and development trends. International Journal of Mechanical Engineering and Technology, 9(12), 618-627.

Hajioff, S. (2007). Health Tourism: 100 years of living science. Imperial College, London, November 2007. Available on: http://www1.imperial.ac.uk/resources/4042628D-B846-4531-BB7D0F8293266C76

Kharlamova N.F. (2013). Assessment and forecast of modern climate changes in the Altai region: monograph. Barnaul: Publishing house Alt. University, $156 \mathrm{p}$.

Kim S. G., Bachleitner R. (2006). Sociology of tourism, or the sociology of travel. Abstract journal. Series 11 Sociology. No. 3, Pp. 90-97.

Korableva, O. N., Kalimullina, O. V., \& Mityakova, V. N. (2018). Innovation activity data processing and aggregation based on ontological modelling. Paper presented at the 2018 4th International Conference on Information Management, ICIM 2018, 1-4. https://doi:10.1109/INFOMAN.2018.8392659

Kolupaev, A. A., Voronkova, O. Y., Vakhrushev, I. B., Adamenko, A. A., Solodkin, V. S., \& Alekhina, N. A. (2019). Corporate identity of lodging establishment as a factor of increasing tourism activity in the region. Paper presented at the Proceedings of the 33rd International Business Information Management Association Conference, IBIMA 2019: Education Excellence and Innovation Management through Vision 2020, 7948-7956.

Krotova E. L. (2003). Recreational-tourist complex of the region: strategic development priorities. Yekaterinburg: Institute of Economics, Ural Branch of the Russian Academy of Sciences, 198 p.

Kvartalnov V.A. et al. (2001). Tourism Management. Tourism and industry systems. M.: Finance and statistics. 270 p.

Lautier, M. (2014) International trade of health services: Global trends and local impact. Health Policy, 118(1), 105113. https://doi:10.1016/j.healthpol.2014.07.004

Lukyanova L.G., Tsybuh V.I. (2004). Recreational complexes. Kiev: Vishcha school, 346 p.

Lunt N., Smith R., Exworthy M., Green S. T., Horsfall D., \& Mannion R. (2011). Medical Tourism: Treatments, Markets and Health System Implications: A scoping review. Organisation for Economic Cooperation and Development (OECD). 55 p. https://www.oecd.org/els/health-systems/48723982.pdf

Madiyarova, A., Blembayeva, A., \& Doszhan, R. (2018). Modern trends in digitalization of tourism industry. Paper presented at the Proceedings of the 32nd International Business Information Management Association Conference, IBIMA 2018 - Vision 2020: Sustainable Economic Development and Application of Innovation Management from Regional Expansion to Global Growth, 7990-7997.

Mirzekhanova Z.G., \& Koltsova A.A. (2013). Geoecological use of recreational potential for the development of health tourism on the example of the Khabarovsk Territory. Problems of Regional Ecology, 6, 203-208.

Mullakhmetov, K. S., Sadriev, R. D., \& Gabaidullina, L. A. (2018). Influence of human capital characteristics on transformation of management and control in the management of social and economic systems. Paper presented at the Proceedings of the 31st International Business Information Management Association Conference, IBIMA 2018: Innovation Management and Education Excellence through Vision 2020, 3562-3572.

Muller H, and Lanz Kauffman E. (2001). Wellness tourism: market analysis of a special health tourism segment and implications for the hotel industry. Journal of Vacation Marketing, 7(1), 5-17.

Nelyubina, E. G., Safina, L. G., Bobkova, E. Y., Korobejnikova, E. V., \& Melysheva, E. P. (2016). Integrative-project model of environmental education in the training system of the students. International Journal of Economics and Financial Issues, 6(1S), 249-255. 


\section{ENTREPRENEURSHIP AND SUSTAINABILITY ISSUES}

ISSN 2345-0282 (online) http://jssidoi.org/jesi/

2020 Volume 7 Number 3 (March)

http://doi.org/10.9770/jesi.2020.7.3(50)

Oborin, M.S. (2011). Aesthetic and psychological assessment of landscape complexes for the development of therapeutic recreation and tourism. Vestnik RUDN, series Ecology and life safety, 2, 89-93.

Ozen, E., \& Grima, S. (2018). Analysis of the Influencing Factors on the Farmers' Take-up of Greenhouse Agricultural Insurance Cover: A Case Study. International Journal of Economics \& Business Administration, 6(4), 14-33.

Pavlov, S. V. (2017). Method evaluation of the human capital with its innovational potential consideration and perspectives of regional development: The example of the Republic of Tatarstan and Volga Federal District regions. Espacios, 38(40)

Preobrazhensky, V. S, Vedenin, Yu. A, Zorin, I. V. (1975). Theoretical Foundations of Recreational Geography. M.: Nauka, 224 p.

Prodanova, N. A., Plaskova, N. S., Dikikh, V. A., Sotnikova, L. V., Nikandrova, L. K., \& Skachko, G. A. (2019). Techniques for assessing the investment attractiveness of a commercial organization based on classical methods of strategic economic analysis. International Journal of Economics and Business Administration, 7(4), 35-46.

Rahman, P. A., Panchenko, A. A., \& Safarov, A. M. (2017). Using neural networks for prediction of air pollution index in industrial city. IOP Conference Series: Earth and Environmental Science, 87(4). https://doi.org/10.1088/1755-1315/87/4/042016

Revyakin V.S., Pomorov S.B., \& Vdovin N.F. (1997). Belokurikhinskaya therapeutic and recreational area. Barnaul: Publishing house of NIIIGP, $154 \mathrm{p}$.

Sandberg, D.S. (2017). Medical tourism: An emerging global healthcare industry. International Journal of Healthcare Management, 10(4), 281-288 https://doi:10.1080/20479700.2017.1296213

Shevyakova, A., Munsh, E., Arystan, M. (2019). Information support for the development of tourism for the diversification of the economy of Kazakhstan, Insights into Regional Development, 1(2), 138-154. https://doi.org/10.9770/ird.2019.1.2(5)

Sharafutdinov, R. I., Gerasimov, V. O., Yagudina, O. V., \& Dmitrieva, I. S. (2017). Research of human capital in view of labour potential of staff: National companies case study. Paper presented at the Proceedings of the 29th International Business Information Management Association Conference - Education Excellence and Innovation Management through Vision 2020: From Regional Development Sustainability to Global Economic Growth, 839-852.

Sharafutdinov, R., Gerasimov, V., Akhmetshin, E., Karasik, E., \& Kalimullina, O. (2019). Inclusive development index in Russia: analysis, methods, possibility of application. Revista Genero \& Direito, 8(4), Special Issue, 231-241.

Singgalen, Y.A., Sasongko, G., Wiloso, P.G. (2019). Community participation in regional tourism development: a case study in North Halmahera Regency - Indonesia. Insights into Regional Development, 1(4), 318-332. https://doi.org/10.9770/ird.2019.1.4(3)

Suprunenko Yu. P. (2003). Mountains are called (Mining and recreational nature use). M.: Trent, 386 p.

Tourism in Russia: A Management Handbook (2015), Chapter: Chapter 7, Publisher: Emerald, Editors: Frederic Dimanche, Lidia Andrades, pp.231-287

Trofimova, L., Prodanova, N., Korshunova, L., Savina, N., Ulianova, N., Karpova, T., \& Shilova, L. (2019). Public sector entities' reporting and accounting information system. Journal of Advanced Research in Dynamical and Control Systems, 11(8 Special Issue), 416424 .

Typology of tourism in relation to health, medical and wellness tourism. Source: Adapted from USAID (2008, p.18) https://www.researchgate.net/publication/302140629 Health and Wellness Tourism

UNSD and UNWTO. International Recommendations for Tourism Statistics, 2008 (IRTS 2008). ST/ESA/STAT/SER.M/83/Rev.1. UN Department of Economic and Social Affairs Statistics Division and UNWTO. Madrid, New York, 2008.

Vetitnev, A.M. Dzubina, A.V., Torgasheva, A.A. (2012). Health tourism: issues of terminology and typology. Vestnik SGUTiKD, 2 (20), $50-56$

Voronkova, O. Y., Iakimova, L. A., Frolova, I. I., Shafranskaya, C. I., Kamolov, S. G., \& Prodanova, N. A. (2019). Sustainable development of territories based on the integrated use of industry, resource and environmental potential. International Journal of Economics and Business Administration, 7(2), 151-163. 


\section{ENTREPRENEURSHIP AND SUSTAINABILITY ISSUES}

ISSN 2345-0282 (online) http://jssidoi.org/jesi/

2020 Volume 7 Number 3 (March)

http://doi.org/10.9770/jesi.2020.7.3(50)

Watkins, M., Imatayeva, A., Kurmangalieva, A., \& Blembayeva, A. (2018). Digital tourism as a key factor in the development of the economy. Economic Annals-XXI, 169(1-2), 40-45. https://doi:10.21003/ea.V169-08

Yemelyanov, V. A., Yemelyanova, N. Y., Nedelkin, A. A., \& Zarudnaya, M. V. (2018). Neural network to diagnose lining condition. Paper presented at the IOP Conference Series: Materials Science and Engineering, 327(2) https://doi:10.1088/1757-899X/327/2/022107

Zeibote, Z., Volkova, T., Todorov, K. (2019). The impact of globalization on regional development and competitiveness: cases of selected regions, Insights into Regional Development, 1(1), 33-47. https://doi.org/10.9770/ird.2019.1.1(3)

Ziyadin, S., Doszhan, R., Saparova, G., \& Omarova, A. (2018). Business tourism as a priority for the development of the tourism industry in the republic of Kazakhstan. Paper presented at the Proceedings of the 32nd International Business Information Management Association Conference, IBIMA 2018 - Vision 2020: Sustainable Economic Development and Application of Innovation Management from Regional Expansion to Global Growth, 3379-3383.

\section{Alexandr N. DUNETS}

Doctor of Geographical Sciences, Professor, Dean of the Faculty of Geography of Altai State University. Research interest: sustainable development of tourism, ecology and environment, functional zoning, mountain region, tourism, the Altai-Sayan Mountains.

ORCID ID: https://orcid.org/0000-0002-3804-6800

\section{Veronika V. YANKOVSKAYA}

Candidate of Economic Sciences, Associate Professor, Plekhanov Russian University of Economics (PRUE): Department of Psychology. The editorial expert of the portal Seychas.ru news stories from the field of economics and management since 2017. She has the professional experience of a consultant: Specialist of the strategic analysis department of Volga-Dnepr Airlines; Expert, Consulting Department, Unicon; Analyst, Department of Federal and Regional Programs, Compulink. Research interests: Reforming the systems and structures of enterprise management. Development and implementation of the strategy. Problems of theory and practice of management, management development model. Humanization of labor of teaching staff (effectiveness and efficiency of teaching staff. Capacity of teaching staff). Information Security.

ORCID ID: https://orcid.org/0000-0003-3614-2169

\section{Alla B. PLISOVA}

PhD in Economics, Associate Professor, Department of State Financial Control, Financial University under the Government of the Russian Federation. Currently engaged in teaching economic and managerial disciplines at the Faculty "Public Administration and Financial Control" and research in the field of state financial control, audit, controlling in the public sector, problems of regional development and economic education. Research interests: sustainable development of regions, state audit, control, internal control systems, training in economics and financial mathematics, controlling.

ORCID ID: https://orcid.org/0000-0001-6075-1488 


\section{ENTREPRENEURSHIP AND SUSTAINABILITY ISSUES}

ISSN 2345-0282 (online) http://jssidoi.org/jesi/

2020 Volume 7 Number 3 (March)

http://doi.org/10.9770/jesi.2020.7.3(50)

\section{Maria V. MIKHAILOVA}

Senior Lecturer, Department of Orthopedic Dentistry, I.M. Sechenov First Moscow State Medical University, Russian Federation, 119991, Moscow, Trubetskaya st., 8-2, is currently teaching clinical dentistry for undergraduate and graduate students and researching to develop a new concept for the treatment and rehabilitation of patients with concomitant pathology using modern digital technologies in orthopedic dentistry. She is a participant in the project 5-top 100 of the I.M. Sechenov First Moscow State Medical University, Russian Federation, the only one among the medical universities of the country, was included in the project to increase the competitiveness of leading Russian universities among the world's leading scientific and educational centers.

ORCID ID: http://orcid.org/0000-0001-9267-1319

\section{Igor B. VAKHRUSHEV}

Associate Professor Department of Tourism, V.I. Vernadsky Crimean Federal University, Russian Federation

Research interest: Business, Management and Accounting, Marketing, Environmental Science, Tourism, Leisure and Hospitality Management, Earth and Planetary Sciences, Geography, Planning and Development

ORCID ID: http://orcid.org/0000-0001-9702-0005

\section{Roman A. ALESHKO}

Associate Professor Department of Information Systems and Technologies, Northern (Arctic) Federal University, Russian Federation. Research interest: Environmental Science, Remote Sensing of Environment, Geoinformation Technologies, Earth and Planetary Sciences, Computer Science, Information Technologies.

ORCID ID: https://orcid.org/0000-0002-1235-8937

Register for an ORCID ID:

https://orcid.org/register

Copyright (C) 2020 by author(s) and VsI Entrepreneurship and Sustainability Center This work is licensed under the Creative Commons Attribution International License (CC BY). http://creativecommons.org/licenses/by/4.0/

C) (i) Open Access 